\title{
IMMIGRATION, STEREOTYPES, AND SOCIAL SECURITY: THE PORTRAYAL OF MIGRANT GROUPS IN PUBLIC DISCOURSE
}

\author{
Dorota DOMALEWSKA, PhD \\ War Studies University, Warsaw, Poland \\ e-mail: d.domalewska@akademia.mil.pl
}

\begin{abstract}
The present paper focuses on the presentation of migrant groups in public discourse, which sheds light on the security-related implications of immigration. In particular, the purpose of the paper is to analyze public discourse on migration to Poland. Qualitative analysis based on a corpus of news reports and online comments on migrant groups in Poland shows that the media coverage of migrant groups focuses on social conflicts and the migrant crisis. Close examination of online comments reveals that regardless of the tone and topic of the article, users' comments posted below the articles are biased, outright and based on repetitive generalisations. Despite few positive reactions, a great degree of intolerance and discrimination has been manifested in public discourse and antagonistic feelings between the minority and majority groups have been identified. Portraying others in a negative way tends to arouse prejudice as well as discriminatory behaviours; thus, it may be concluded that that negative stereotypes are deeply rooted in Polish society and are likely to bring about negative expectations towards various ethnic groups.
\end{abstract}

Keywords: immigration, stereotypes, discourse analysis, migrant groups, refugees, media

\section{Introduction}

The modern world is beset with numerous problems that threaten social security and stability. Immigration is one of the burning issues that raises public concern and intense debate on how to achieve an adequate balance between the benefits of 
immigration, national security, public safety, as well as human rights and refugee law. On the one hand, a great number of refugees flee their war-ravaged countries. On the other hand, the massive inflow of migrant groups has been for economic reasons. Both waves of migration affect the target country's economy, national security, international relations, social structure and national identity. From the point of view of social security, migration affects the state's social structure both horizontally and vertically. The former relates to the change in mindset caused by the considerable impact of incoming cultures, whereas the latter entails the deepest form of integration when national groups stop seeing themselves as distinct ${ }^{1}$. The structure of Polish society is undergoing rapid changes due to ongoing migration (both emigration and immigration), demographic changes, and globalisation. A high rate of immigration leads to the formation of society where various distinct social groups co-exist. These groups vary in their ethnic, religious, linguistic background, but they also differ in appearance, values and traditions. On the one hand, there is a need to shape the attitudes of tolerance and openness where people will respect one another. On the other hand, accepting social changes is a long-term process and although immigrants can find their new home in Poland, they may frequently experience indifference, hostility, and ostracism. That is why this paper intends to analyse the threat to national security posed by social factors, in particular immigration and stereotypes of migrant groups reinforced in public discourse in Poland. In particular, the purpose of the paper is to analyze public discourse on migration to Poland. The following research questions guided the study: (1) How is immigration portrayed in public discourse? (2) What stereotypical opinions about migrant groups are expressed in public discourse?

\section{Immigration to Poland}

In recent years, Poland has undergone changes in the labour market caused by the rapid development of some sectors such as technology, a high migration rate and shifting demographics. A growing number of foreigners decide to reside in

1 M. Brzeziński, Bezpieczeństwo społeczne z perspektywy bezpieczeństwa wewnętrznego, Zeszyty Naukowe WSOWL, 3(169), 2013. 
Poland either for work or study ${ }^{2}$. Poland's accession to the European Union in 2004 marks the beginnings of the inflow of migrants, mainly temporary workers, and the inflow from the former Soviet Union republics. Large numbers of refugees have also been seeking asylum ${ }^{3}$, primarily from Chechnya, Ukraine, Georgia, and Armenia. Poland has become a country of both emigration and immigration, which calls for immigration and integration legislation to be modified ${ }^{4}$. However, non-EU citizens are not easily granted residence permits, which can be obtained when migrants set up a company in Poland, get a job or pursue education. Polish legislation is not flexible in granting foreigners permits, although some liberalisation has been introduced. Migration legislation has undergone major changes since the mid-1990s as a result of Poland's attempts and subsequent accession to the European Union and the need to unify and consolidate policies. Several regularisation programmes (in 2003, 2007, and 2012) were introduced in order to curb the number of undocumented migrants living in Poland. Other legislative changes have been implemented to combat illegal immigration, regulate asylum seeking, control the local border traffic regime along the Eastern border, and assist the migration inflow to respond to continuing labour market needs ${ }^{5}$; for example, since 1 Jan 2017, foreigners have found it easier to prolong their stay or change job during their stay in Poland and their wages increased by $33 \%$ in the period from May to July $2017^{6}$. Most migrants come to work in unskilled professions (construction, logistics, and private households) and settle down in Mazovian voivodeship (39\% of all migrants). The vast majority of migrants come from the former Soviet Union countries. The most numerous group of immigrants are Ukrainians (over one million already live and work here) who have left their

2 According to the Office for Foreigners, the number of residence permit applicants rose by $87 \%$ since 2015 . Between Jan - Jun 2017, 89,000 applicants applied for residence permits: $87 \%$ applied for temporary stay, $11 \%$ for permanent, whereas $2 \%$ applied for EU residency. Moreover, 3,000 foreigners were asylum seekers, mostly (93\%) from the former Soviet Union countries (Russia, Ukraine, Tajikistan, Kyrgyzstan, Armenia, Georgia, and Belarus). 5,000 EU citizens registered their stay in Poland (https://udsc.gov.pl/trendy-migracyjne-wi-polowie-2017-r/).

3 E. Kępińska, M. Kindler, Poland, in A. Triandafyllidou, R. Gropas (eds) European immigration: sourcebook, Alershot: Ashgate 2013.

4 M. Duszczyk, Polska polityka imigracyjna a rynek pracy, Warsaw: Oficyna Wydawnicza ASPRA-JR 2012.

5 E. Kępińska, M. Kindler, Poland ...

6 K. Nowakowska, Pracodawcy boją się odpływu Ukraińców z Polski. Płaca więcej. http:// praca.gazetaprawna.pl/artykuly/1057092,zarobki-ukraincow-w-polsce.html 
home country due to the military conflict and economic instability in Ukraine. Other groups include Vietnamese, Russians, Belarusians, Chinese, Armenians, and Turks ${ }^{7}$. Foreign students form a separate group of migrants. Their number has tripled over the last 3 years and reached 65,096 in 2016/2017 ${ }^{8}$. They come mostly from Ukraine (half of them), Belarus7,8\%), India (3,3\%) and other, mostly European countries. Duszczyk ${ }^{9}$ argues that Polish immigration legislation should be more lenient towards foreign students (e.g. facilitating foreign students to get a job, removing legal obstacles connected to prolonging their stay in Poland, and funding scholarships) because they are the most likely to influence economic development and counteract the demographic problems Poland is facing.

The analysis of statistical data published by the Polish Central Statistical Office shows a dramatic change in immigration patterns since 2004, when Poland joined the European Union. In 2004, the greatest number of migrants came from Germany, the US and Ukraine ${ }^{10}$, whereas in 2017 migrants come mainly from Ukraine, Vietnam and Russia. In 2004, immigrants' preferred places of residence were the Malopolski, Mazovian and Silesian voivodships) ${ }^{11}$, while in 2017, the Mazovian voivodeship was the most popular region. The number of residence permits granted to foreigners has risen by $48 \%$ since $2014^{12}$. This statistical data shows the rapid growth and essential dynamics of immigration to Poland and, despite numerous advantages, migration trends are a source of concern, mainly related to economic security and threat to cultural identity. Migration has raised heated debates among Poles, especially since the number of reported hate crimes fuelled by racism and xenophobia are on the rise (the hate crime rate rose from 200 in 2010 to 1548 in 2015) ${ }^{13}$. Taking into consideration both the rise of migration

7 J. Konieczna-Sałamatin, Imigracja do Polski wświetle danych urzędowych, in J. KoniecznaSałamatin (ed.) Imigranci o wysokich kwalifikacjach na polskim rynku pracy. Raport z badań 2014-2015. Wyd. iSEE and Fundacja Nasz Wybór, Warsaw 2015.

8 http://www.studyinpoland.pl/en/index.php/news/71-over-65-000-foreign-students-inpoland.

9 M. Duszczyk, Polska polityka imigracyjna ...

10 K. Iglicka, A. Wejnar, Wptyw rozszerzenia Unii Europejskiej na ruchy migracyjne na terenie Polski, Centrum Stosunków Międzynarodowych, Warsaw 2005.

11 Ibidem.

12 https://udsc.gov.pl/statystyki/raporty-okresowe/raport-roczny-legalizacja-pobytu/2015-2/.

13 K. Fejfer, W 2016 byty o trzy przestępstwa $z$ nienawiści mniej niż w 2015 i trzy razy więcej niż w 2014, https://oko.press/2016-byly-o-przestepstwa-nienawisci-niz-2015-razywiecej-niz-2014/ 
and hate crime, it is interesting to consider how Poles perceive immigrants and what stereotypes of migrant groups are perpetuated.

\section{Stereotypes}

The notion of the stereotype was first defined by Walter Lippmann as a picture of various phenomena that we carry in our heads that helps us handle complex reality thanks to the processes of simplification and generalisation ${ }^{14}$. Stereotypes are unjustified if they are caused by faulty thinking, overgeneralisations, or if they are at variance with facts, are too rigid, contain improper attribution patterns or form the basis for prejudice and discrimination rationalisation. Recently, the notion of stereotypes has shed the negative aspect which was emphasised in the past and its role in information processing and categorisation, but without negative connotation, has been highlighted. Thus, Hamilton and Trolier ${ }^{15}$ define stereotypes as cognitive categories that are used in processing information about others, while Rahn ${ }^{16}$ refers to stereotypes as "cognitive structures that contain citizens' knowledge, beliefs, and expectancies" that in a natural way result from categorisation processes of human cognition.

Stereotypes refer to cognitive and affective associations (i.e. evaluations, preferences, emotions, and moods) but they are also affected by socio-motivational and cultural factors prevalent in the social context. The evaluative component of the stereotype can be highly diverse, e.g. a stereotype can contain both a positive and negative feature. Stereotypes persist because they play significant social and cognitive functions. First, stereotyping entails both the simplification of complex reality and the enhancement of social representations that fosters the formation of meaningful divisions of the world which later facilitate understanding of the behaviour of an individual. Moreover, stereotypes serve affective functions as they

14 K. H. McGill, The school-teacher stareotype, Journal of Educational Psychology, 4(10), 642-650, 1931.

15 D. L. Hamilton, T.K. Trolier, Stereotypes and stereotyping: An overview of the cognitive approach, 1986.

16 W. M. Rahn, The role of partisan stereotypes in information processing about political candidates, American Journal of Political Science, 37(2), 472-796, 1993. 
involve not onlybeliefs about others butalso certain emotions and their evaluations. The categorisation process also influences the formation of identity. Therefore, stereotyping involves the following processes: categorising others on the basis of easily noticeable features, e.g. gender and race that distinguish one social group from another; attributing some qualities to all members of the group; attributing some qualities to any individual of the group. Stereotypes refer to three types of phenomena: linguistic phenomena; individual and sequence of actions as well as décor and scenarios; socio-cultural representations that can relate to celebrities, people (ethnic groups, professions), places, objects, institutions, disciplines (e.g. law, mathematics), epochs (e.g. Antiquity), literary movements (e.g. Romanticism), cultural phenomena, experiences, and concepts ${ }^{17}$. Furthermore, stereotypes are commonly partly contradictory to facts (usually based on insufficient evidence) or contain exaggerated generalisations of the world (the kernel-of-truth hypothesis); however, they seem to be absolutely true. Stereotypes are also static, which is related to the fact that they are frequently created irrespective of the individual experience. Moreover, stereotypes are verbal; a word conjures the content of the stereotype $^{18}$. They make members of the out-group homogeneous and uniform. The stereotyping process also controls interpersonal antagonisms, conflicts and aggression.

The process of stereotyping unconsciously affects cognition and behaviour in several ways: stereotypes affect the way behaviour can be categorised; they make people interpret behaviour or quality differently; stereotypes of an outgroup influence the perception of individual members of the group; they finally affect our judgements. However, not all stereotypes are based on inaccurate overgeneralisations of the reality. A large body of research proves that some stereotypes can be accurate, particularly when they refer to gender $^{19}$, race,

17 M. Kamecka, Les stereotypes et l'enseignement des langues etrangeres, in K. Bogacki, H. Mitatliuk, L. Serada (eds) Language, Society, and Problems of Intercultural Communication, Wydawnictwo Uniwersytetu w Białymstoku, Białystok 2005.

18 J. Błuszkowski, Stereotypy narodowe w świadomości Polaków, Dom Wydawniczy ELIPSA, Warsaw 2003.

19 C. McCauley, K. Thangavelu, Individual differences in sex stereotyping of occupations and personality traits, Social Psychology Quarterly, 54(3), 267-279, 1991. 
nationality, physical attractiveness, academic performance of ethnic groups, other students, and experimentally created groups ${ }^{20}$.

Stereotypes are acquired in the enculturation process; they are inherent in culture. Their formation is affected and reinforced by significant others, particularly parents, their views and behavioural patterns, but also mass media and school can transfer certain notions and emotional reactions about other people. Thus, children learn the content of stereotypes through different cultural mechanisms. At the youngest age, they acquire categorisation with the categories of age, gender and race. Later, children learn about the characteristic features of every category and, either through direct experience or through observation, learn about emotional reactions provoked by the categories. Finally, people figure out if their behaviour is appropriate or not towards the social group. They also learn what behaviour is acceptable under which circumstances and for what kind of people. Race and gender stereotypes are learned even earlier than youngsters can form definite concepts about these groups ${ }^{21}$.

Exposure to the media also plays a part in instilling stereotypic notions The media are biased in portraying various groups as well as gender and social roles (especially in advertising); therefore, they stimulate universality of different phenomena which viewers later accept. Apart from culture, social interactions and personal experience play a role in the formation and maintenance of stereotypes. The individual can challenge the stereotypes that are culturally held (although sometimes such stereotypes can affect our behaviour).

\section{National stereotypes}

National stereotypes are mental representations of other peoples and nations; they are cultural stereotypes common to the nation, durable and resistant to change. Moreover, they are so fixed that when we encounter an individual coming from a national group who is totally different from our stereotypical image of this

20 D. J. Schneider, They psychology of stereotyping, the Guilford Press, New York; London 2004.

21 Ibidem 
group, we classify the individual so as to fit him or her into the framework formed by the stereotype. Nonetheless, regardless of the fact that we tend to act towards others according to our stereotypical thinking and categorise their behaviour so that it confirms the stereotype, a growing body of research shows that national stereotypes are partly accurate. Research studies show that people from various cultures agree on the content of commonly-held national stereotypes (slight variations in the content of the stereotypes results from the varying character of intergroup contact), and, what is more, the stereotypes about national groups conform with the group's perception of itself ${ }^{22}$. These findings can be explained by the fact that the national culture affects its members ${ }^{23}$ and that historical events the nation goes through shape their experiences and character.

National stereotypes are a part of national identity and include an evaluative component of ourselves and our own nation (our national group is perceived more favourably) and the evaluation of the changeable position of our nation when compared with other nations ${ }^{24}$. National stereotypes are activated, for example, during a political crisis, armed conflict, national holiday, international sports matches, and vacation abroad. In peace time, negative aspects of national stereotypes are frequently neglected; however, in a situation of tension, mistrust and negative connotations revive. In the event of of extreme conflict, the "mirror image" phenomenon takes place when inhabitants of antagonistic countries portray one another with the same features ${ }^{25}$.

National stereotypes perform several functions:

i. They are a popular point of reference which let us construct both other people and the reality and facilitate communication.

ii. They give emphasis to the feeling of belonging; that is why national stereotypes reinforce bonds between members of the in-group.

22 W. Koomen, M. Bähler, National stereotypes: Common representations and ingroup favouritism, European Journal of Social Psychology, 26, 325-331, 1996; J. Krueger, Probabilistic national stereotypes, European Journal of Social Psychology, 26, 961-980, 1996; E. T. Prothro, Cross-cultural patterns of national stereotypes, Journal of Social Psychology, 40, 53-59, 1954.

23 D. J. Schneider, The psychology of...

24 W. Koomen, M. Bähler, National stereotypes...

25 U. Bronfenbrenner, The mirrorimage in Soviet-American relations: A social psychologist's report, Journal of Social Issues, 17(3), 45-56, 1961. 
iii. They strengthen common values by contrasting "our" habits and values with the habits and values of "others".

iv. They frequently emphasise the positive aspect of "our" community, which is different from other out-groups.

v. They are used to include or exclude individuals or groups whose habits and values are perceived as a threat to "our" values (i.e. discrimination).

vi. They help to express our loyalty to the community.

vii. On the basis of national stereotypes, the nation creates a "scapegoat" at a time of crisis $^{26}$.

The stereotyping process contrasts the in-group with the out-group; the ingroup is always at an advantage because the positive evaluation of our in-group is transferred to our higher self-esteem.

\section{Public discourse on immigration}

Public discourse in the media plays a significant role in how the public understands social conflicts and immigration. Geschke et al. ${ }^{27}$ lend support to the fact that the media reinforce stereotypes and prejudice. The researchers found that journalists tend to use linguistic bias in articles related to minority groups, which leads to a higher level of prejudice. Similarly, Schemer ${ }^{28}$ (2012) found that media coverage affects readers' stereotypical attitudes towards migrant groups, but only among a low to moderately-informed audience. Well-informed readers are more likely to resist the effects of presentation of immigrants in news reports.

Locally, there is still a paucity of research studies on minority groups in Poland, even though due to the dynamic nature of immigration in Poland, research findings

26 J. Berting, C. Villain-Gandossi, Rola i znaczenie stereotypów narodowych w stosunkach międzynarodowych: Podejście interdyscyplinarne, in T. Walas (ed.) Narody i stereotypy, Międzynarodowe Centrum Kultury, Kraków 1995.

27 D. Geschke et.al. Effects of linguistic abstractness in the mass media: How newspaper articles shape readers' attitudes toward migrants, Journal of Media Psychology: Theories, Methods, and Applications, 22(3), 99-104, 2010.

28 C. Schemer, The influence of news media on stereotypical attitudes toward immigrants in a political campaign, Journal of Communication, 62(5), 739-757, 2012. 
expire at a rapid rate. Jura and Kałużyńska ${ }^{29}$ carried out a detailed analysis on the presentation of migrant groups in online and traditional media. The researchers found that most migrant groups, except the Chinese and Belarussians, arouse negative opinions and stereotypical attitudes. Chechens, Romanies, and Ukrainians are the three ethnic groups that provoke the greatest number of negative opinions in the public discourse, especially in right-wing newspapers. On the other hand, Jóźwiak, Konieczna-Sałamatin and Tudorowsk ${ }^{30}$ in their study of public discourse on immigrants found that the depiction of migrant groups has become more positive since 1996. Similarly, Grzymała-Kazłowska ${ }^{31}$ found that, in comparison to the West European press, the discourse on immigrants in Poland is more positive, which is related to the fact that immigration is a new phenomenon in Poland and the country has not experienced the negative effects of the inflow of migrant groups. The researcher investigated how immigrants, focusing on two migrant groups: Ukrainians and Vietnamese, were presented in daily newspapers in the period 1993-2003. She also found that political discourse on minority groups was repetitive, with the topic of immigrants raised in the context of economy, European integration, terrorism, Polish nationalism, multiculturalism, and immigration trends.

\section{Methodology}

Taking into consideration the mixed sentiments and opinions about immigrants manifested in public discourse, the present study sets out to analyse how the users of social media react towards the topic of immigration. The following research questions guided the study: (1) How is immigration portrayed in public discourse?

29 J. Jura, K. Kałużyńska, Obraz obcokrajowców i imigrantów w polskich mediach tradycyjnych $i$ internetowych, in Konieczna-Sałamatin, J. (ed.) Imigranci o wysokich kwalifikacjach na polskim rynku pracy. Warsaw 2015.

30 I. Jóźwiak, J. Konieczna-Sałamatin, M. Tudorowski, Bez cudzoziemców bylibyśmy ubożsi. Wizerunek obcokrajowców na tamach polskiej prasy, Instytut Spraw Publicznych, Warsaw 2010.

31 A. Grzymała-Kazłowska, Konstruowanie innego wizerunku imigrantów w Polsce Wydawnictwo Uniwersytetu Warszawskiego, Warsaw 2007. 
(2) What stereotypical opinions about migrant groups are expressed in public discourse?

The research was conducted in the following steps. First, articles on immigration and migrant groups published online in the domestic section of four political weekly magazines with the greatest circulation were identified. The magazines selected for analysis included Gość Niedzielny, Polityka, Newsweek Polska, and Tygodnik do Rzeczy ${ }^{32}$. The articles were published between 1 January and 31 July 2017. Next, readers' comments posted below the online articles on immigration and migrant groups in Poland were analyzed. The research focused on comments posted by readers of online papers, as this form allows a large degree of anonymity and, thus, freedom in expressing views. Like-minded users can hide behind their on-line nickname without revealing their identity, which encourages them to voice their true opinions that in real life are not always openly expressed.

The corpus consisted of 3828 online comments posted below 110 articles on migrant groups in Poland (limited to the domestic section of papers) published between 1 January and 31 July 2017. Traditional Content Analysis was used to examine comments posted by readers. This research technique has been selected because it allows "the systematic, objective, quantitative analysis of message characteristics" ${ }^{\prime 3}$ and is well grounded in both theory ${ }^{34}$ and research studies $^{35}$. Moreover, this method is the most appropriate to reach the objectives of the study, since most comments were text-based without hyperlinks and the distribution of comments is rather limited. The most important structural features of comments were coded, including the number of comments, sentiment, and voiced stereotypes.

32 In April 2017, the magazines achieved these sales figures: Gość Niedzielny $(134,036)$, Polityka (122,525), Newsweek Polska $(110,811)$, Tygodnik Do Rzeczy $(45,189)$ (http://www. wirtualnemedia.pl/artykul/sprzedaz-tygodnikow-opinii-kwiecien-2017\#).

33 K. A. Neuendorf, The content analysis guidebook, Sage. Thousand Oaks, CA. 2016, p. 1.

34 Ibidem; D. Ezzy, Qualitative Analysis, London and New York: Routledge, 2013.

35 A. Grzymała-Kazłowska, Konstruowanie...; J. Jura, K. Kałużyńska, Obraz obcokrajowców... 


\section{Results and discussion}

In the analysed period (January - July 2017), immigration was a widely-covered topic; however, media coverage focused on five main topics. The articles mostly referred to social conflicts and the migrant crisis. It should be remembered that the research is limited to domestic affairs; thus, articles found in the domestic section of magazines were analysed. Figure 1 shows a detailed breakdown of articles into several groups, including the migrant crisis (these articles reported the influx of immigrants from war torn regions, attempts to solve the problem, the international pressure exerted on the Polish government and the reaction of politicians, public figures and the Catholic church), attitude (these articles focused on Polish society, its attitude towards immigrants/immigration, and surveys measuring public fears), crime (news reports described either crimes committed by immigrants in Poland or instances of law-breaking by Poles against immigrants). A great number of articles reported on the tragic circumstances after a 21-year-old Pole was stabbed to death by North African immigrants in the city of Ełk on 1 January 2017 and the riots that erupted in the aftermath), life in Poland (these articles portrayed immigrant life in Poland), Poland as a target destination (these articles focused on immigrants who decided to settle down in Poland). It is interesting to note that these articles covered various migrant groups, mostly Ukrainians, but also Indians and Jews.

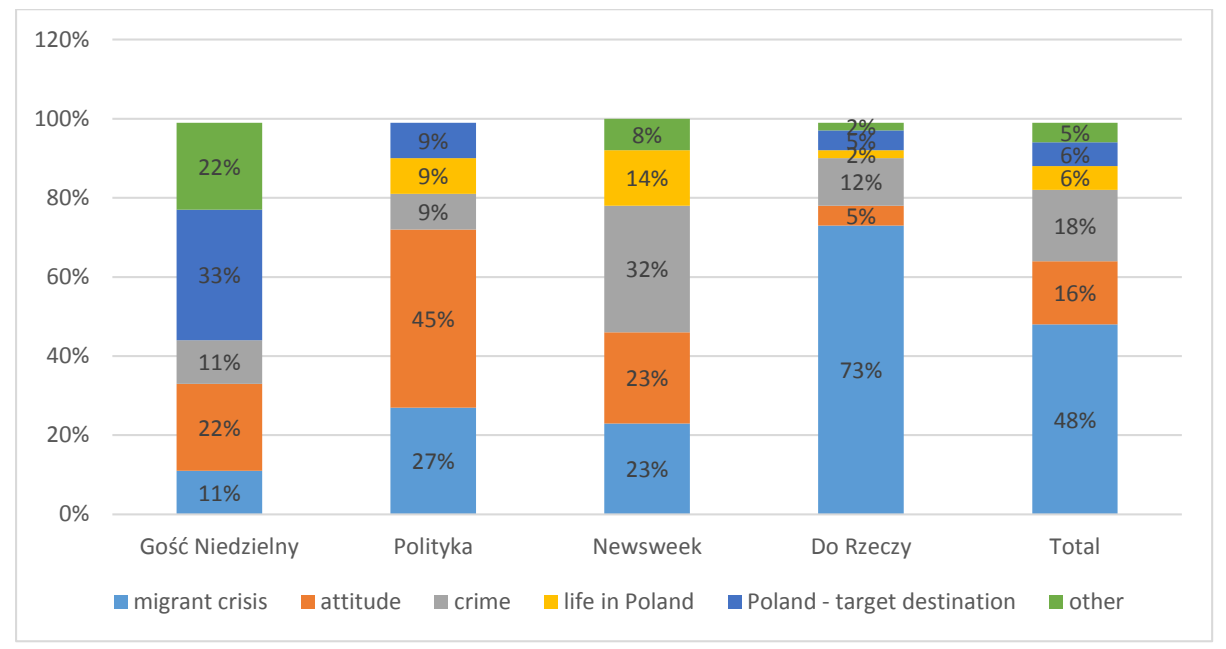

Figure 1. Thematic breakdown of migration-related articles 
The character of the news media reflects the discourse on immigration: a Catholic weekly (Gość Niedzielny) focuses on the positive aspect of migration, while political papers focus on current events and social conflicts, such as the migrant crisis and violence. Newsweek presents more sensational articles, whereas the liberal-conservative weekly, Do Rzeczy, reports heavily on the mounting tension over Poland's attitude to asylum seekers.

Most articles published online were commented on avidly (the corpus contains 3828 comments broken down into those published in Gość Niedzielny - 1.8\%, Polityka - 0.6\%, Newsweek - 40\% and Do Rzeczy - 57\%). Comments can be broadly classified into two groups: comments that either reflect the content of the article or criticise other users (mostly disapproving of their ignorance and shortsightedness). The present analysis is limited to content comments that reveal the users' opinions on the inflow of immigrants to Poland. Close examination of comments shows a predominantly negative sentiment towards immigrants. The opinions expressed by the users can be classified into several groups. First, the vast majority of users opposed the influx of both immigrants and asylum seekers, justifying their opinions with security and economic reasons. Some comments are particularly harsh calling for extradition of immigrants and expressing views that immigrants either came to claim benefits or commit acts of terror. Views are expressed that the migration crisis is a planned action aimed at destroying our Christian tradition and culture. Some users argue that there is no place for immigrants in Poland, which is a homogeneous society and the tradition of multiethnicity died out and cannot be revived. Such harsh comments opposing immigration can be juxtaposed with remarks calling for help. These views can be divided into two groups. First, a number of users agree that immigrants and asylum seekers need to be given a helping hand, but it is not 'our' responsibility to help them. Former colonial empires, the USA, and religious leaders, such as bishops, are most frequently listed as entities that should be responsible for helping immigrants. (It is interesting to note that one article indeed presented a bishop who offered his residence to asylum seekers, but this gesture was condemned as worthless because the bishop offered something that did not belong to him.) Finally, a few users expressed the view that helping others is our obligation. They frequently refer to Christian and moral ideals or cognitive values ("getting to know other cultures can widen our horizons", "we can become wiser and more openminded"). Among the users who are in favour of helping immigrants, the majority 
claim that instead of inviting them to other countries, help should be provided in the refugees' homeland.

Apart from investigating the attitude towards immigrants, the analysis focused on stereotypes prevalent in Polish society. First, while commenting on the problem of immigration, users expressed a wide range of auto-stereotypes with a diverse evaluative component. Positive auto-stereotypes include well-educated Poles, hospitable, and open-minded ("Poland nowadays is multicultural and open for other societies, be it religious or lay"). However, it is negative stereotypes that are prevalent in the corpus. The users describe their ingroup with the following generalisations: poor, drunkards, ignorant, retarded, intolerant, racist, and Catholic scoundrels.

The study also revealed stereotypes of immigrants that perpetuate among Poles. Most comments targeted asylum seekers; thus, most stereotypes refer to this group. Refugees are perceived as uneducated, aggressive, discriminatory towards women, and as criminals and terrorists killing others to order. The following labels were most frequently used to describe immigrants: pack of immigrants, scoundrels, swine, and vagrants. Ukrainians are the second most commonly discussed group. They have been described as hardworking but malicious, mercenary and sleazy. Finally, Indians have been lauded as hardworking with delicious Indian cuisine.

\section{Conclusions}

The findings of the study show that despite few positive reactions, a great degree of intolerance and discrimination has been manifested in public discourse. Antagonistic feelings between the minority and majority groups have been identified, which may affect the process of integration of immigrants into Polish society. The research study shows the media coverage of migrant groups focuses on social conflicts and the migrant crisis Europe is facing. Regardless of the tone and topic of the article, users' comments posted below the articles are biased, blatant, and based on repetitive generalisations. Given that online comments reflect netizens' opinions, it is staggering to see that online conversations perpetuate so much stigma and reinforce stereotypes, which relates to the findings of Jura and 
Kałużyńska ${ }^{36}$ and Geschke et $\mathrm{al}^{37}$. Considering the impact of online conversations on the general public, the results of the study show that negative stereotypes are deeply rooted in Polish society and are likely to bring about negative expectations towards various ethnic groups. Portraying others in a negative way tends to arouse prejudice as well as discriminatory behaviour. The topic of immigration has become a source of heated debate in the public discourse. On the one hand, immigrants are seen as a threat to Polish culture, economy and social security. A number of netizens draw attention to immigrants being terrorists, living on social benefits. On the other hand, the problem of asylum seekers has been raised; however, most netizens believe that help should be provided in the refugees' homeland rather than inviting them to settle in Western countries. A few users of social media express positive opinions on immigrants remarking on their input towards enriching the target culture, commenting on their delicious cuisine, hard work and perseverance. Thus, the present findings run contrary to the findings reported in the previous studies ${ }^{38}$ which presented evidence of more positive presentation of migrant groups in public discourse. This fact can be justified by the basic methodological difference between the studies: the present study analysed netizens' opinions expressed anonymously in comments below articles on immigrants, whereas other studies focused on investigating discourse of the media coverage. The anonymity of Internet communication lowers the barriers of political correctness and the cultural and social expectations of appropriateness. On the other hand, newspapers cover issues that are either sensational or have become the source of heated debate; thus, netizens react strongly to the content of articles they have read.

36 J. Jura, K. Kałużyńska, Obraz obcokrajowców...

37 D. Geschke et.al. Effects of linguistic...

38 A. Grzymała-Kazłowska, Konstruowanie...; I. Jóźwiak, J. Konieczna-Sałamatin, M. Tudorowski, Bez cudzoziemców... 


\section{Bibliography}

Błuszkowski J., Stereotypy narodowe w świadomości Polaków, Dom Wydawniczy ELIPSA, Warsaw 2003.

Berting J., Villain-Gandossi C., Rola $i$ znaczenie stereotypów narodowych $w$ stosunkach międzynarodowych: Podejście interdyscyplinarne, in T. Walas (ed.) Narody i stereotypy, Międzynarodowe Centrum Kultury, Kraków 1995.

Bronfenbrenner U., The mirror image in Soviet-American relations: A social psychologist's report, Journal of Social Issues, 17(3), 45-56, 1961.

Brzeziński M., Bezpieczeństwo społeczne z perspektywy bezpieczeństwa wewnętrznego, Zeszyty Naukowe WSOWL, 3(169), 2013.

Duszczyk M., Polska polityka imigracyjna a rynek pracy, Warsaw: Oficyna Wydawnicza ASPRA-JR 2012. Ezzy D., Qualitative Analysis London and New York: Routledge, 2013. Fejfer K., W 2016 byty o trzy przestępstwa z nienawiści mniej niż w 2015 i trzy razy więcej niż $w$ 2014, https://oko.press/2016-byly-o-przestepstwa-nienawisci-niz-2015-razywiecej-niz-2014/.

Geschke D., Sassenberg K., Ruhrmann G., Sommer D., Effects of linguistic abstractness in the mass media: How newspaper articles shape readers' attitudes toward migrants, Journal of Media Psychology: Theories, Methods, and Applications, 22(3), 99-104, 2010.

Grzymała-Kazłowska A., Konstruowanie innego wizerunku imigrantów w Polsce Wydawnictwo Uniwersytetu Warszawskiego, Warsaw 2007.

Hamilton D. L., Trolier T. K., Stereotypes and stereotyping: An overview of the cognitive approach, 1986.

Iglicka K., Wejnar A., Wptyw rozszerzenia Unii Europejskiej na ruchy migracyjne na terenie Polski, Centrum Stosunków Międzynarodowych, Warsaw 2005.

Jura J., Kałużyńska K., Obraz obcokrajowców i imigrantów w polskich mediach tradycyjnych $i$ internetowych, in Konieczna-Sałamatin, J. (ed.), Imigranci o wysokich kwalifikacjach na polskim rynku pracy. Warsaw 2015.

Jóźwiak I., Konieczna-Sałamatin J., Tudorowski M., Bez cudzoziemców bylibyśmy ubożsi. Wizerunek obcokrajowców na tamach polskiej prasy, Instytut Spraw Publicznych, Warsaw 2010.

Kamecka M., Les stereotypes et l'enseignement des langues etrangeres, in K. Bogacki, H. Mitatliuk, L. Serada (eds), Language, Society, and Problems of Intercultural Communication, Wydawnictwo Uniwersytetu w Białymstoku, Białystok 2005.

Kępińska E., Kindler M., Poland, in A. Triandafyllidou, R. Gropas (eds), European immigration: sourcebook, Alershot: Ashgate 2013.

Konieczna-Sałamatin J., Imigracja do Polski w świetle danych urzędowych, in J. KoniecznaSałamatin (ed.), Imigranci o wysokich kwalifikacjach na polskim rynku pracy. Raport z badań 2014-2015, Wyd. iSEE and Fundacja Nasz Wybór, Warsaw 2015. 
Koomen W., Bähler M., National stereotypes: Common representations and ingroup favouritism, European Journal of Social Psychology, 26, 325-331, 1996.

Krueger J., Probabilistic national stereotypes, European Journal of Social Psychology, 26, 961-980, 1996.

McCauley C., Thangavelu K., Individual differences in sex stereotyping of occupations and personality traits, Social Psychology Quarterly, 54(3), 267-279, 1991.

McGill K.H., The school-teacher stareotype, Journal of Educational Psychology, 4(10), 642650, 1931.

Neuendorf K.A., The content analysis guidebook, Sage. Thousand Oaks, CA, 2016.

Nowakowska K., Pracodawcy bojq się odptywu Ukraińców z Polski. Płacq więcej, http:// praca.gazetaprawna.pl/artykuly/1057092,zarobki-ukraincow-w-polsce.html.

Prothro E.T., Cross-cultural patterns of national stereotypes, Journal of Social Psychology, 40, 53-59, 1954.

Rahn W.M., The role of partisan stereotypes in information processing about political candidates, American Journal of Political Science, 37(2), 472-796, 1993.

Schemer C., The influence of news media on stereotypic attitudes toward immigrants in a political campaign, Journal of Communication, 62(5), 739-757, 2012.

Schneider D.J., The psychology of stereotyping, the Guilford Press, New York; London 2004.

https://udsc.gov.pl/trendy-migracyjne-w-i-polowie-2017-r/

http://www.studyinpoland.pl/en/index.php/news/71-over-65-000-foreign-students-inpoland. 